\title{
Identifikasi Penentuan Skala Prioritas Penanganan Genangan atau Banjir Di Kecamatan Karawang Barat
}

\author{
Trisha Ajeng Larasaty ${ }^{1}$, M. Candra Nugraha ${ }^{2}$, Etih Hartati ${ }^{3}$ \\ ${ }^{1,2,3}$ Jurusan Teknik Lingkungan, Fakultas Teknik Sipil dan Perencanaan, Institut Teknologi Nasional, Bandung \\ Jl. P.H.H Mustopa No. 23 Bandung 40124
}

*Koresponden email: trishaajengl@ gmail.com

Diterima: 7 September 2020

Disetujui: 1 Oktober 2020

\begin{abstract}
West Karawang District is a center of local activities with a service scope the whole Karawang Regional with most populous region by 142.509 persons. Based on Karawang Regional Spatial Plans Year 2011 2031, West Karawang Sub-district is a flooded vulnerable area when rain season. That area is along the Citarum River stream with. Priority scale determination of flood is done with comparison method of the existing flood condition with the parameters in Peraturan Menteri Pekerjaan Umum dan Perumahan Rakyat No.12 Tahun 2014 tentang Penyelenggaraan Sistem Drainase Perkotaan. There were 13 flood points in West Karawang District with the highest priority scale, Tanjungpura Sub-District. In Tanjungpura Sub-District, there are 3 flood points with a height of 50-30 cm, $1 \mathrm{Ha}$ of flood area, and the length of flood lasts for 10 hours. The puddle is located in a densely populated residential area which causes a lot of losses to residents.
\end{abstract}

Keywords: West Karawang District, pool, flood, priority scale, spatial planning

\begin{abstract}
Abstrak
Kecamatan Karawang Barat merupakan sentral kegiatan lokal dengan lingkup pelayanan untuk seluruh wilayah Kabupaten Karawang dengan jumlah penduduk terpadat yaitu 142.509 jiwa. Berdasarkan Rencana Tata Ruang Wilayah(RTRW) Kabupaten Karawang Tahun 2011-2031, Kecamatan Karawang Barat merupakan kawasan rawan bencana banjir saat terjadi musim hujan. Kawasan tersebut berada di sepanjang aliran Sungai Citarum. Penentuan skala prioritas genang/banjir dilakukan dengan metode membandingkan kondisi genangan/banjir eksisting dengan parameter pada Peraturan Menteri Pekerjaan Umum No.12 Tahun 2014 tentang Penyelenggaraan Sistem Drainase Perkotaan. Berdasarkan skala prioritas tertinggi didapatkan 13 titik genangan/banjir pada Kecamatan Karawang Barat yaitu pada Kelurahan Tanjungpura. Pada Kelurahan Tanjungpura terdapat 3 titik genangan dengan tinggi genangan berkisar 50-30 cm, luas genangan $1 \mathrm{Ha}$, dan lamanya genangan berlangsung selama $10 \mathrm{jam}$. Genangan berlokasi pada daerah pemukiman padat penduduk yang menyebabkan banyak kerugian yang dialami warga.
\end{abstract}

Kata Kunci: Kecamatan Karawang Barat, genangan, banjir, skala prioritas, tata ruang

\section{Pendahuluan}

Menurut RTRW Kabupaten Karawang Tahun 2011-2031 Kecamatan Karawang Barat merupakan kawasan rawan bencana banjir saat terjadi musim hujan karena kawasan tersebut berada di sepanjang aliran Sungai Citarum [1]. Kecamatan Karawang Barat juga memiliki jumlah penduduk terbanyak di Kabupaten Karawang dengan jumlah penduduk 142.509 jiwa [2] dengan kepadatan penduduk 4.392 jiwa $/ \mathrm{km}^{2}$ [3]. Hal tersebut mengakibatkan terjadinya pembukaan lahan untuk menunjang kegiatan dan kebutuhan masyarakat, mengakibatkan berkurangnya daerah resapan air. Adanya tata guna lahan yang berubah pada Kecamatan Karawang Barat disebabkan bertumbahnya jumlah penduduk sehingga berpengaruh terhadap persoalan drainase. Hal tersebut menyebabkan berkurangnya daerah resapan air dan dapat menimbulkan permasalahan lingkungan, seperti banjir [4].

Saat musim hujan tiba dengan curah hujan yang tinggi, maka daerah dengan tingkat kepadatan penduduk tertinggi cenderung memiliki daerah resapan yang rendah, sehingga menyebabkan air hujan yang turun menjadi air aliran permukaan. Aliran air permukaan yang melebihi kapasitas saluran drainase tersebut menyebabkan genangan/banjir [5]. Selain itu, saluran drainase menjadi tidak dapat berfungsi dengan baik disebabkan oleh adanya penumpukan sampah dan sedimen [6].

Drainase memiliki pengertian yaitu mengalirkan, menguras, membuang, dan atau mengalirkan air limpa[7]. Sistem drainase merupakan bangunan air yang dirangkai agar dapat mengurangi atau 
membuang air yang tidak dapat dialirkan pada suatu kawasan atau lahan, sehingga fungsinya dapat optimal[8]. Oleh karena itu, dalam penanggulangan masalah banjir, sistem drainase yang dimiliki harus baik.

Penilaian pra dan pasca bencana merupakan cara untuk mengurangi dampak banjir dikarenakan upaya pengendalian banjir yang sulit [9]. Pra bencana bermanfaat sebagai early warning system sehingga dapat diketahui lokasi prioritas penanganan banjir pada daerah rawan banjir [10]. Dalam upaya mengatasi permasalahan banjir pada Kecamatan Karawang Barat diperlukan penyusunan skala prioritas. Skala prioritas berfungsi untuk mengetahui titik genangan/banjir yang paling membutuhkan penanganan. Penentuan skala prioritas ditentukan dengan perbandingan kondisi eksisting dan parameter pada Permen PUNo.12 Tahun 2014. Parameter yang dibandingkan yaitu tinggi genangan, luas genangan, lama genangan, dan frekuensi genangan. Selain itu penilaian skala prioritas juga dilihat dari aspek kerugian ekonomi, gangguan sosial dan fasilitas pemerintah, kerugian dan gangguan tranportasi, kerugian pada daerah perumahan, serta kerugian hak milik pribadi [11]. Penelitian ini bertujuan untuk melakukan skala prioritas penanganan genangan/banjir pada Kecamatan Karawang Barat. Manfaat penelitian ini yaitu mendapatkan tingkat prioritas genangan/banjir untuk memperbaiki sistem drainase di Kecamatan Karawang Barat.

\section{Metodologi Penelitian}

\section{Lokasi penelitian dan Prosedur Penelitian}

Penelitian dilakukan pada Kecamatan Karawang Barat, Kabupaten Karawang, Jawa Barat dengan cakupan 8 (delapan) kelurahan [2], yaitu Adiarsa Barat, Nagasari, Karawang Kulon, Tanjung Pura, Tanjung Mekar, Karang Pawitan, Mekarjati, dan Tunggakjati. Berikut ini jenis data untuk menentukan skala prioritas dapat dilihat pada Tabel 1.

Tabel 1. Data yang digunakan

\begin{tabular}{|c|c|c|}
\hline Jenis Data & Metode Pengumpulan Data & Data yang didapatkan \\
\hline Data Primer & $\begin{array}{l}\text { - Wawancara } \\
\text { - Survey }\end{array}$ & $\begin{array}{l}\text { 1. Karakteristik genangan meliputi : } \\
\text { - Tinggi genangan } \\
\text { - Luas genangan } \\
\text { - Lamanya genangan } \\
\text { - Frekuensi genangan } \\
\text { 2. Survey kondisi lapangan : } \\
\text { Melakukan survey kondis } \\
\text { lapangan untuk melihat fasilitas } \\
\text { sosial maupun pemerintah }\end{array}$ \\
\hline Data Sekunder & $\begin{array}{l}\text { Pengambilan data dari pihak } \\
\text { stakeholder terkait }\end{array}$ & $\begin{array}{l}\text { Adapun data sekunder yang } \\
\text { dibutuhkan yaitu: } \\
\text { a. Peta kepadatan penduduk } \\
\text { diperoleh dari BAPPEDA Kab } \\
\text { Karawang } \\
\text { b. Peta administrasi diperoleh dar } \\
\text { Kecamatan Karawang Barat } \\
\text { c. Peta penggunaan lahan diperoleh } \\
\text { dari BAPPEDA Kab. Karawang } \\
\text { d. Tingkat kepadatan peduduk yang } \\
\text { didapatkan dari Karawang dalam } \\
\text { angka Tahun } 2018 \\
\end{array}$ \\
\hline
\end{tabular}

Sumber: Hasil analisis, 2019

\section{Metode Pengolahan Data}

Daerah genangan merupakan air yang tergenang pada kawasan atau daerah akibat ketidakmampuan saluran drainase dalam menampung debit aliran. Akibatnya terjadi kerugian harta benda dan dapat mengganggu aktivitas masyarakat. Menurut Permen PU No. 12 Tahun 2014 jaringan drainase pada perkotaan seharusnya mampu mengalirkan air dengan baik, standar pelayanan sistem jaringan drainase tidak memperbolehkan genangan yang terjadi lebih dari $30 \mathrm{~cm}$, selama 2 jam, dan tidak lebih dari 2 kali setahun [11].

Langkah selanjutnya yaitu dilakukan penilaian pada lokasi dari genangan pada setiap kelurahan hingga didapatkan skala prioritas untuk Kecamatan Karawang Barat. Penilaian dilakukan untuk setiap titik genangan yang didapatkan dengan bobot nilai berdasarkan tingkat urgensi dari kondisi genangan 
yang didapatkan untuk masing-masing parameter. Gambar 1 merupakan diagram alir dalam melakukan penelitian,

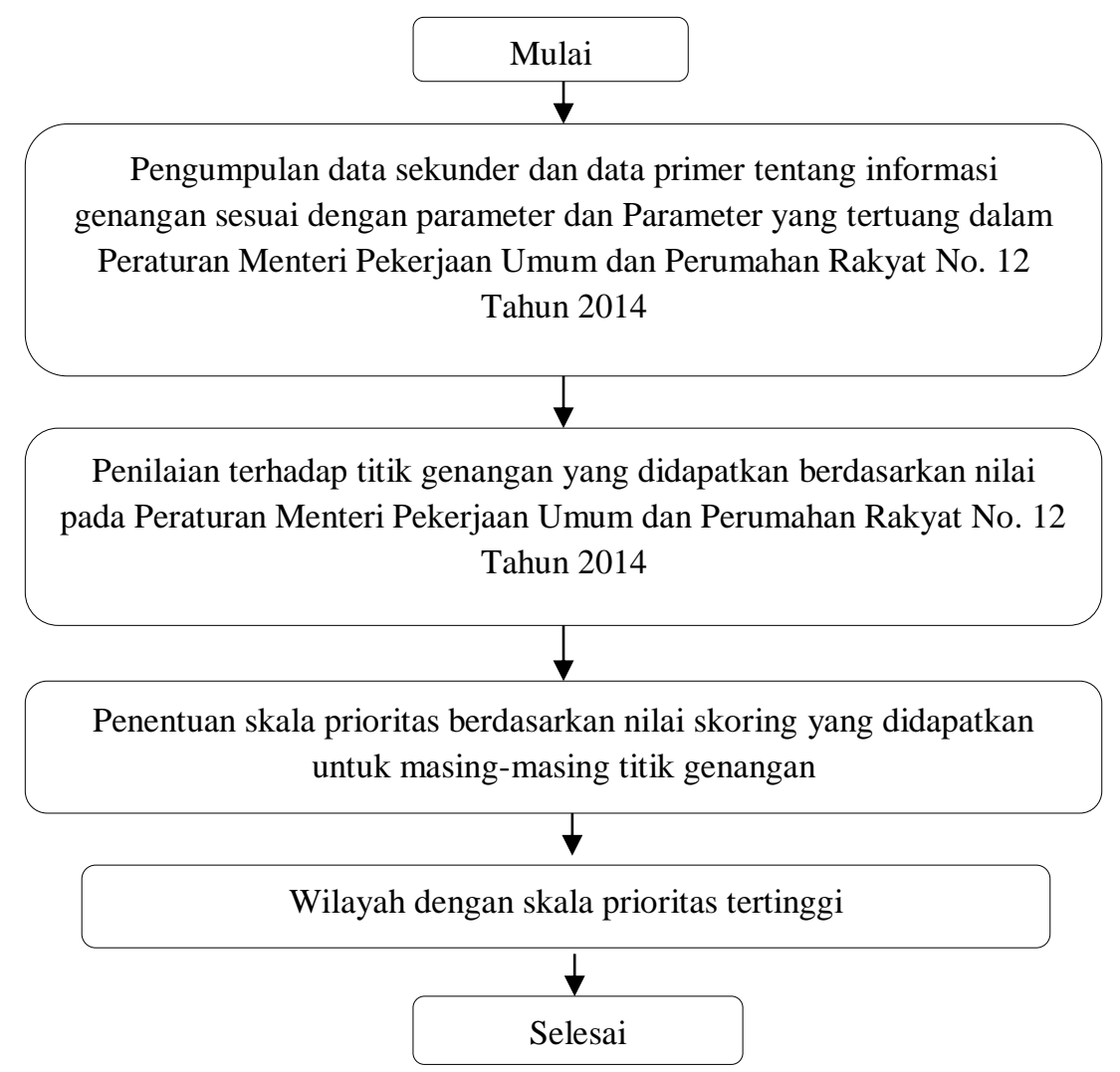

Gambar 1. Tahapan perencanaan

Adapun Parameter penanganan daerah genangan, yaitu meliputi kedalaman, luas, lamanya, dan frekuensi dari genangan, serta aspek yang menimbulkan kerugian dari segi ekonomi, kerugian terhadap fasilitas sosial, terganggunya fasilitas transportasi, kerugian di daerah perumahan, dan barang-barang hak milik pribadi yang mengacu pada Permen PU No. 12 Tahun 2014. Bobot nilai dari masing-masing Parameter dapat dilihat pada Tabel 2 - Tabel 7.

Tabel 2. Nilai parameter genangan/banjir

\begin{tabular}{|c|c|c|c|c|}
\hline \multicolumn{3}{|c|}{ Parameter Genangan/Banjir } & \multirow[t]{2}{*}{ Nilai } & \multirow[t]{2}{*}{$\%$ Nilai } \\
\hline 1. & Kedalaman Genangan & Satuan & & \\
\hline & Lebih dari 0,50 & & & $100 \%$ \\
\hline & $0,30-0,50$ & & & $75 \%$ \\
\hline & $0,20-0,30$ & $\mathrm{~m}$ & & $50 \%$ \\
\hline & $0,10-0,20$ & & 35 & $25 \%$ \\
\hline & Kurang dari 0,10 & & & 0 \\
\hline & Luas Genangan & Satuan & & \\
\hline & $>8$ & & & $100 \%$ \\
\hline & $4-8$ & & & $75 \%$ \\
\hline & $2-4$ & $\mathrm{Ha}$ & & $50 \%$ \\
\hline & 1- 2 & & 25 & $25 \%$ \\
\hline & $<1$ & & & 0 \\
\hline & Waktu Genangan & Satuan & & \\
\hline & $>8$ & & & $100 \%$ \\
\hline & $4-8$ & & & $75 \%$ \\
\hline & $2-4$ & jam & & $50 \%$ \\
\hline & $1-2$ & & 20 & $25 \%$ \\
\hline & $<1$ & & & 0 \\
\hline
\end{tabular}




\begin{tabular}{ccc}
\hline Parameter Genangan/Banjir & Nilai & $\%$ Nilai \\
\hline Frekuensi Genangan & & \\
Sangat sering (10 kali/tahun) & & $100 \%$ \\
Sering (6 kali/tahun) & & $75 \%$ \\
Kurang sering (3 kali/tahun) & \multirow{2}{*}{20} & $50 \%$ \\
Jarang (1 kali/tahun) & & $25 \%$ \\
Tidak pernah & & $0 \%$ \\
\hline
\end{tabular}

Sumber: [11]

Tabel 3. Parameter kerugian ekonomi

\begin{tabular}{lcc}
\hline \multicolumn{1}{c}{ Parameter } & Tingkat Kerugian & Nilai \\
\hline $\begin{array}{l}\text { Genangan terjadi pada kawasan industri, kawasan } \\
\text { komersial dan kawasan perkantoran padat }\end{array}$ & Tinggi & 100 \\
$\begin{array}{l}\text { Genangan terjadi pada kawasan industri dan kawasan } \\
\text { komersial yang kurang padat }\end{array}$ & Sedang & 65 \\
$\begin{array}{l}\text { Genanga mempengaruhi atau terjadi di kawasan perumahan } \\
\text { dan/atau kawasan pertanian (dalam kawasan perkotaan } \\
\text { yang terbatas) } \\
\begin{array}{l}\text { Terjadi genangan pada kawasan yang jarang penduduknya } \\
\text { dan tidak produktif }\end{array}\end{array}$ Kecil & 25 \\
\hline
\end{tabular}

Sumber: [11]

Tabel 4. Parameter gangguan sosial dan fasilitas pemerintah

\begin{tabular}{lcc}
\hline \multicolumn{1}{c}{ Parameter } & Tingkat Kerugian & Nilai \\
\hline $\begin{array}{l}\text { Genangan terjadi pada kawasan yang banyak terdapat fasilitas } \\
\text { sosial dan fasilitas pemerintah }\end{array}$ & Tinggi & 100 \\
$\begin{array}{l}\text { Genangan terjadi di kawasan yang sedikit terdapat fasilitas } \\
\text { sosial dan fasilitas pemerintah }\end{array}$ & Sedang & 65 \\
$\begin{array}{l}\text { Genangan mempengaruhi atau terjadi di kawasan yang } \\
\text { pelayanan sosial dan fasilitas pemerintah terbatas }\end{array}$ & Kecil & 30 \\
Jika tidak ada fasilitas sosial dan fasilitas pemerintah & Sangat kecil & 0 \\
\hline
\end{tabular}

Sumber: [11]

Tabel 5. Parameter kerugian dan gangguan transportasi

\begin{tabular}{lcc}
\hline \multicolumn{1}{c}{ Parameter } & Tingkat Kerugian & Nilai \\
\hline $\begin{array}{l}\text { Genangan terjadi pada kawasan yang jaringan transportasinya } \\
\text { padat }\end{array}$ & Tinggi & 100 \\
$\begin{array}{l}\text { Genangan terjadi di kawasan yang jaringan transportasinya } \\
\text { kurang padat }\end{array}$ & Sedang & 65 \\
$\begin{array}{l}\text { Genangan mempengaruhi atau terjadi di kawasan yang } \\
\text { jaringan transportasinya terbatas } \\
\text { Jika tidak ada jaringan jalan }\end{array}$ & Kecil & 30 \\
\hline
\end{tabular}

Sumber: [11]

Tabel 6. Parameter kerugian pada daerah pemukiman

\begin{tabular}{lcc}
\hline \multicolumn{1}{c}{ Parameter } & Tingkat Kerugian & Nilai \\
\hline Genangan air/banjir terjadi pada pemukiman sangat padat & Tinggi & 100 \\
\hline $\begin{array}{l}\text { Genangan air/banjir terjadi pada pemukiman yang padat } \\
\text { Genangan air/banjir mempengaruhi atau terjadi di yang hanya } \\
\text { pada beberapa bangunan pemukiman }\end{array}$ & Sedang & 65 \\
\hline
\end{tabular}

$\begin{array}{lll}\text { Jika tidak ada pemukiman pada daerah genangan air/banjir } & \text { Sangat kecil } & 0\end{array}$


Tabel 7. Parameter kerugian harta milik pribadi

\begin{tabular}{|c|c|c|}
\hline Parameter & Tingkat Kerugian & Nilai \\
\hline$>80 \%$ nilai milik pribadi & Tinggi & 100 \\
\hline $80 \%$ dari nilai milik pribadi & Sedang & 65 \\
\hline$<40 \%$ nilai milik pribadi & Kecil & 30 \\
\hline Tidak ada kerugian milik pribadi & Sangat kecil & 0 \\
\hline
\end{tabular}

Data yang telah dibandingkan dengan keenam tabel diatas, kemudian dihitung nilai untuk setiap parameternya. Nilai yang didapatkan dari setiap parameter kemudian ditambahkan. Untuk penentuan nilai. dilakukan dengan perhitungan sebagai berikut:

1. Melakukan survey pada daerah penelitian dari parameter Peraturan Menteri Pekerjaan Umum No. 12 Tahun 2014

2. Menilai kondisi geangan setelah itu menentukan bobot nilai menurut parameter.

a. Penentuan Perhitungan untuk Tabel 2.

Data dari Tabel 2. didapatkan dari pengumpulan data primer yang meruapakan hasil penilaian dari kedalaman, luas dan waktu genangan serta data frekuensi terjadi genangan, kemudian dilakukan perhitungan berikut ini.

$\Sigma$ Nilai $=$ Nilai $\mathrm{x}(\%$ Nilai $)[13]$

b. Penentuan Nilai Untuk Tabel 2 - Tabel 7.

Sedangkan untuk Tabel 2 - Tabel 7. nilai didapatkan dengan membanding data yang didapat disesuai dengan parameter-parameter untuk setiap Parameter.

c. Penentuan Skala Prioritas

Menurut Permen PU No. 12 Tahun 2014, nilai dari seluruh parameter kemudian di jumlahkan dan nilai tertinggi merupakan daerah dengan tingkat prioritas pertama, makin rendah nilainya makin rendah pula tingkat prioritasnya.

\section{Hasil dan pembahasan}

\section{Gambaran Umum Kecamatan Karawang Barat}

Kecamatan Karawang Barat berada pada wilayah pusat pemerintahan Kabupaten Karawang yang direncanakan sebagai kawasan pemukiman wilayah 1 Karawang [14]. Luas wilayah Kecamatan Karawang Barat sebesar $37,35 \mathrm{~km}^{2}$ atau 2,13\% dari luas wilayah Kabupaten Karawang. Wilayah Kecamatan Karawang Barat mencakup delapan kelurahan, yang terdiri dari Adiarsa Barat, Nagasari, Karawang Kulon, Tanjung Pura, Tanjung Mekar, Karang Pawitan, Mekarjati, dan Tunggakjati. Dengan total jumlah penduduk pada Tahun 2017 yaitu 142.509 jiwa [2].

Kondisi iklim pada wilayah Kecamatan Karawang Barat memiliki iklim tropis dengan suhu minimal $28^{\circ} \mathrm{C}$ dan suhu maksimal $33^{\circ} \mathrm{C}$. Curah hujan di Kecamatan Karawang Barat rata-rata 148 $\mathrm{mm}^{3} /$ bulan dengan jumlah hari hujan sebanyak 110 hari. Secara topografi, wilayah Karawang Barat terletak di daerah dataran yang datar. Ketinggian wilayah Karawang Barat berada pada rata-rata 30 meter diatas permukaan laut (mdpl) dan variasi kemiringan lahan 0-2\%. Kecamatan Karawang Barat memiliki dua sistem DAS yaitu DAS citarum dan DAS Cibadar Dua [2].

Pada Kecamatan Karawang Barat terdapat genangan pada delapan Kelurahan dengan Parameter genangan yang berbeda-beda. Lokasi terjadinya genangan dapat dilihat pada Tabel 8.

Tabel 8. Lokasi Terjadinya Genangan pada Kecamatan Karawang Barat

\begin{tabular}{cc}
\hline Kelurahan & Nama Daerah \\
\hline Karang Pawitan & Jalan Kartini (A1) \\
& RW 03 Jatiudik (A2) \\
Tunggakjati & RW 02 Jatiudik (A3) \\
& RW 06 Jatiilir (A4) \\
Nagasari & Bakati Asem (A5) \\
& Gang Bajong (A6) \\
Karawang Kulon & Keponcol Tengah (A7) \\
Adiarsa Barat & Jalan Citarum (A8) \\
\hline
\end{tabular}




\begin{tabular}{cc}
\hline Tanjung Mekar & Kp. Tanjung Mekar RW 8 (A9) \\
& RW 03 Gempol Rawa (A10) \\
Tanjung Pura & RW 04 Gempol Rawa (A11) \\
& RW 03 Gang Lotus (A12) \\
Mekarjati & Perbatasan Antara Tunggakjati (A13) \\
\hline Sumber :Hasil observasi, 2019 &
\end{tabular}

Gambar 2 merupakan lokasi genangan pada Kecamatan Karawang Barat sesuai dengan tata guna lahan pada daerah genangan.

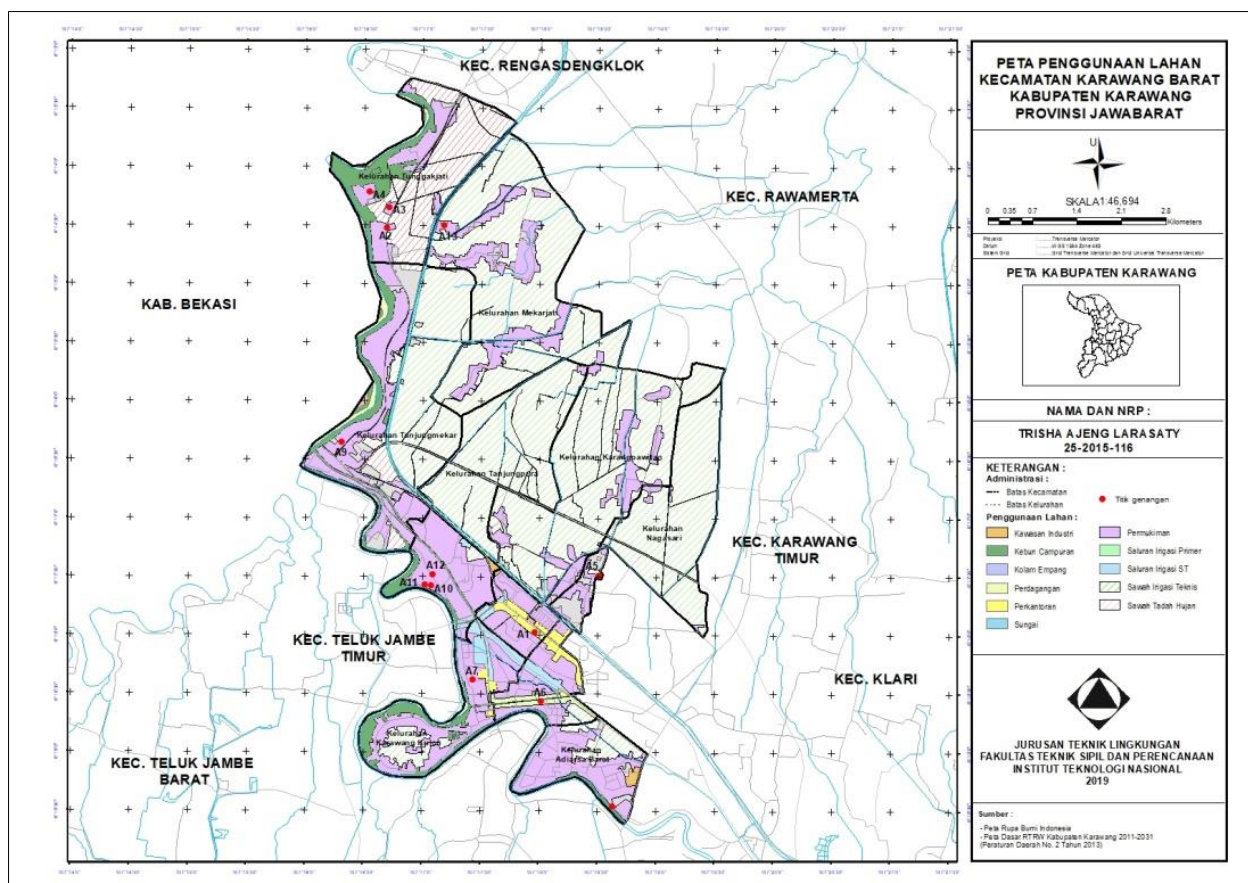

Gambar 2. Lokasi genangan menurut tata guna lahan [15]

\section{Penilaian Kondisi Genangan}

Penilaian kondisi genangan dilakukan dengan data yang didapatkan. Penilaian yang dilakukan mengacu pada Menurut Peraturan Menteri Pekerjaan Umum No. 12 Tahun 2014 sehingga didapatkan bobot nilai sesuai dengan hasil penilaian.

a. Karakteristik Genangan

Kondisi genangan didapatkan dari hasil wawancara kepada pihak stakeholder terkait. Berikut hasil dari yang didapatkan untuk kondisi karakterisitik genangan dapat dilihat pada Tabel 9.

Tabel 9. Rekapitulasi nilai karakteristik genangan

\begin{tabular}{cccccccccc}
\hline Lokasi & $\begin{array}{c}\text { Tinggi } \\
\text { (cm) }\end{array}$ & Nilai & $\begin{array}{c}\text { Luas } \\
\text { (ha) }\end{array}$ & Nilai & $\begin{array}{c}\text { Lama } \\
\text { (jam) }\end{array}$ & Nilai & $\begin{array}{c}\text { Frekuensi } \\
\text { (per tahun) }\end{array}$ & Nilai & $\begin{array}{c}\text { Rekapitulasi } \\
\text { Nilai (1) }\end{array}$ \\
\hline A1 & $>5$ & 0 & $>1$ & 0 & $>1$ & 0 & - & 0 & 0 \\
A2 & 50 & 26,25 & $>1$ & 0 & 1,5 & 5 & 3 & 10 & 41,25 \\
A3 & 30 & 26,25 & $>1$ & 0 & 2 & 5 & 3 & 10 & 41,25 \\
A4 & 40 & 26,25 & $>1$ & 0 & 1 & 5 & 3 & 10 & 41,25 \\
A5 & 5 & 0 & $>1$ & 0 & $>1$ & 0 & 3 & 10 & 10 \\
A6 & 5 & 0 & $>1$ & 0 & $>1$ & 0 & 3 & 10 & 10 \\
A7 & $>9$ & 0 & $>1$ & 0 & $>1$ & 0 & - & 0 & 0 \\
A8 & 5 & 0 & $>1$ & 0 & $>1$ & 0 & - & 0 & 0 \\
A9 & 15 & 8,75 & $>1$ & 0 & 2 & 5 & - & 0 & 8,75 \\
A10 & 50 & 26,25 & 1 & 6,25 & 10 & 20 & 6 & 15 & 67,5 \\
A11 & 35 & 26,25 & 1 & 6,25 & 10 & 20 & 5 & 15 & 67,5 \\
A12 & 30 & 26,25 & 1 & 6,25 & 10 & 20 & 6 & 15 & 67,5 \\
A13 & 60 & 35 & $>1$ & 0 & $>1$ & 0 & 3 & 10 & 45 \\
\hline
\end{tabular}

Sumber :Hasil analisis, 2019 
b. Parameter Kerugian Sektor Ekonomi

Kondisi genangan pada sektor ekonomi didapatkan dari peta penggunaan lahan sehingga dapat diketahui sebarahan industri, pertanian, maupun komersil. Untuk mengetahui nilai kerugian ekonomi dilihat pada Tabel 10.

Tabel 10. Penilaian parameter kondisi kerugian ekonomi

\begin{tabular}{|c|c|c|c|c|c|}
\hline Lokasi & $\begin{array}{c}\text { Industri, Kawasan } \\
\text { Komersil, dan Daerah } \\
\text { Perkantoran Padat }\end{array}$ & $\begin{array}{c}\text { Industri dan } \\
\text { Daerah Komersil } \\
\text { yang kurang padat }\end{array}$ & $\begin{array}{c}\text { Kawasan } \\
\text { Perumahan dan } \\
\text { Pertanian }\end{array}$ & $\begin{array}{l}\text { Kawasan yang } \\
\text { tidak produktif }\end{array}$ & Nilai (2) \\
\hline A1 & - & - & $\sqrt{ }$ & - & 30 \\
\hline $\mathrm{A} 2$ & - & - & $\sqrt{ }$ & - & 30 \\
\hline A3 & - & - & $\sqrt{ }$ & - & 30 \\
\hline A4 & - & - & $\sqrt{ }$ & - & 30 \\
\hline A5 & - & - & $\sqrt{ }$ & - & 30 \\
\hline A6 & - & - & $\sqrt{ }$ & - & 30 \\
\hline A7 & - & - & $\sqrt{ }$ & - & 30 \\
\hline A8 & - & - & $\sqrt{ }$ & - & 30 \\
\hline A9 & - & - & $\sqrt{ }$ & - & 30 \\
\hline A10 & - & - & $\sqrt{ }$ & - & 30 \\
\hline A11 & - & - & $\sqrt{ }$ & - & 30 \\
\hline A12 & - & - & $\sqrt{ }$ & - & 30 \\
\hline A13 & - & - & $\sqrt{ }$ & - & 30 \\
\hline
\end{tabular}

Sumber :Hasil analisis, 2019

Dari Tabel 10 diketahui bahwa kerugian ekonomi seluruhnya terjadi pada kawasan perumahan, hal tersebut dikarenakan Kecamatan Karawang Barang merupakan daerah terpada pada Kabupaten Karawang.

c. Parameter Fasilitas Sosial dan Fasilitas Pemerintah

Kondisi genangan pada fasilitas sosial dan fasilitas pemerintah didapatkan dari hasil wawancara dengan mengetahui fasilitas sosial dan fasilitas pemerintah yang terdapat pada daerah genangan maupun sekitarnya. Untuk mengetahui kerugian pada Parameter ini dapat dilihat pada Tabel 11.

Tabel 11. Penilaian parameter fasilitas sosial dan fasilitas pemerintah

\begin{tabular}{|c|c|c|c|c|c|}
\hline \multirow[b]{2}{*}{ Lokasi } & \multicolumn{4}{|c|}{ Pelayanan Sosial dan Fasilitas Pemerintah } & \multirow[b]{2}{*}{ Nilai (3) } \\
\hline & Padat & Sedikit & Terbatas & $\begin{array}{c}\text { Tidak } \\
\text { Terdapat }\end{array}$ & \\
\hline A 1 & - & $\sqrt{ }$ & - & - & 65 \\
\hline A 2 & - & - & - & $\sqrt{ }$ & 0 \\
\hline A 3 & - & - & - & $\sqrt{ }$ & 0 \\
\hline A 4 & - & - & - & $\sqrt{ }$ & 0 \\
\hline A 5 & - & - & - & $\sqrt{ }$ & 0 \\
\hline A 6 & - & - & - & $\sqrt{ }$ & 0 \\
\hline A 7 & - & - & $\sqrt{ }$ & - & 30 \\
\hline A 8 & - & - & $\sqrt{ }$ & - & 30 \\
\hline A 9 & - & - & - & $\sqrt{ }$ & 0 \\
\hline A 10 & - & $\sqrt{ }$ & - & - & 65 \\
\hline A 11 & - & $\sqrt{ }$ & - & - & 65 \\
\hline A 12 & - & $\sqrt{ }$ & - & - & 65 \\
\hline A 13 & - & $\sqrt{ }$ & - & - & 65 \\
\hline
\end{tabular}

Sumber : Hasil analisis, 2019

Dari Tabel 11 dapat diketahui pada beberapa lokasi genangan tidak mempengaruhi gangguan sosial dan fasilitas pemerintah, pada lokasi genangan A10, A11, A12, dan A13 terdapat sedikit fasilitas sosial dan pemerintahan, dan pada lokasi A8 dan A9 terdapat fasilitas sosial dan pemerintaham hanya saja jumlahnya terbatas.

d. Parameter Gangguan Transportasi

Kondisi genangan pada Parameter ini didapatkan dari hasil wawancara terhadap pengaruh genangan kepada jalur transportasi. Berikut hasil penilaian dari Parameter ini dilihat pada Tabel 12. 
Tabel 12. Penilaian parameter gangguan transportasi

\begin{tabular}{lccccc}
\hline & \multicolumn{4}{c}{ Kerugian Gangguan Transportasi } & \\
\cline { 2 - 5 } Lokasi & Padat & $\begin{array}{c}\text { Kurang } \\
\text { Padat }\end{array}$ & Terbatas & $\begin{array}{c}\text { Tidak } \\
\text { Terdapat }\end{array}$ & Nilai (4) \\
\hline A1 & - & $\sqrt{ }$ & - & - & 65 \\
A2 & $\sqrt{ }$ & - & - & - & 100 \\
A3 & $\sqrt{ }$ & - & - & - & 100 \\
A4 & $\sqrt{ }$ & - & - & - & 100 \\
A5 & $\sqrt{ }$ & - & - & - & 100 \\
A6 & $\sqrt{ }$ & - & - & - & 100 \\
A7 & $\sqrt{ }$ & - & - & - & 100 \\
A8 & $\sqrt{ }$ & - & - & - & 100 \\
A9 & $\sqrt{ }$ & - & - & - & 100 \\
A10 & - & $\sqrt{ }$ & - & - & 65 \\
A11 & - & $\sqrt{ }$ & - & - & 65 \\
A12 & - & $\sqrt{ }$ & - & - & 65 \\
A13 & - & & - & - & 65 \\
\hline
\end{tabular}

Sumber :Hasil analisis, 2019

Pada Tabel 12. dapat diketahui lokasi genangan pada jalur transportasi yang cukup padat dan kurang padat, dengan artian genangan yang terjadi pada Kecamatan Karawang Barat menganggu jalur mobilitas warga.

e. Parameter Kerugian pada Kawasan Pemukiman

Kondisi genangan pada Parameter ini didapatkan dari hasil wawancara tentang kepadatan penduduk dan juga dilihat dari tingkat kepadatan penduduknya pada daerah tersebut. Berikut hasil penilaian dari Parameter kerugian pada kawasan pemukiman dapat dilihat pada Tabel 13.

Tabel 13. Penilaian parameter kerugian pada kawasan pemukiman

\begin{tabular}{|c|c|c|c|c|c|}
\hline \multirow[b]{2}{*}{ Lokasi } & \multicolumn{4}{|c|}{ Tingkat Kepadatan Penduduk } & \multirow[b]{2}{*}{ Nilai (5) } \\
\hline & $\begin{array}{c}\text { Perumahan } \\
\text { Padat }\end{array}$ & $\begin{array}{c}\text { Perumahan } \\
\text { Kurang Padat }\end{array}$ & $\begin{array}{l}\text { Beberapa } \\
\text { Bangunan }\end{array}$ & $\begin{array}{c}\text { Tidak } \\
\text { Terdapat }\end{array}$ & \\
\hline$\overline{\mathrm{A} 1}$ & $\sqrt{ }$ & - & - & - & 100 \\
\hline A2 & $\sqrt{ }$ & - & - & - & 100 \\
\hline A3 & $\sqrt{ }$ & - & - & - & 100 \\
\hline A4 & $\sqrt{ }$ & - & - & - & 100 \\
\hline A5 & - & - & $\sqrt{ }$ & - & 30 \\
\hline A6 & - & - & $\sqrt{ }$ & - & 30 \\
\hline A7 & - & $\sqrt{ }$ & - & - & 65 \\
\hline A8 & - & $\sqrt{ }$ & - & - & 65 \\
\hline A9 & $\sqrt{ }$ & - & - & - & 100 \\
\hline A 10 & $\sqrt{ }$ & - & - & - & 100 \\
\hline A11 & $\sqrt{ }$ & - & - & - & 100 \\
\hline A12 & $\sqrt{ }$ & - & - & - & 100 \\
\hline A13 & - & $\sqrt{ }$ & - & - & 65 \\
\hline
\end{tabular}

Sumber :Hasil analisis, 2019

Pada Tabel 13. dapat diketahui lokasi genangan mayoritas berada pada daerah perumahan padat. Sedangkan, untuk lokasi genangan A7, A8 dan A13 berada pada daerah dengan perumahan tidak begitu padat dan pada lokasi A5 dan A6 berapa pada daerah yang terdapat beberapa bangunan.

f. Parameter Harta Milik Pribadi

Kondisi genangan pada Parameter ini didapatkan dari hasil wawancara mengenai tingkat kerugian dari genangan yang terjadi terhadap harta milik pribadi. Berikut ini hasil penilaian hak milik pribadi dapat dilihat pada Tabel 14. 
Tabel 14. Penilaian parameter kerugian harta milik pribadi

\begin{tabular}{|c|c|c|c|c|c|}
\hline \multirow[b]{2}{*}{ Lokasi } & \multicolumn{4}{|c|}{ Tingkat Kerugian Hak Milik Pribadi } & \multirow[b]{2}{*}{ Nilai (6) } \\
\hline & $>80 \%$ & $80 \%$ & $<40 \%$ & $\begin{array}{c}\text { Tidak Terdapat } \\
\text { Kerugian }\end{array}$ & \\
\hline A1 & - & - & $\sqrt{ }$ & - & 30 \\
\hline $\mathrm{A} 2$ & - & $\sqrt{ }$ & - & - & 65 \\
\hline A3 & - & $\sqrt{ }$ & - & - & 65 \\
\hline A4 & - & $\sqrt{ }$ & - & - & 65 \\
\hline A5 & - & - & $\sqrt{ }$ & - & 30 \\
\hline A6 & - & - & $\sqrt{ }$ & - & 30 \\
\hline A7 & - & - & - & $\sqrt{ }$ & 0 \\
\hline A8 & - & - & - & $\sqrt{ }$ & 0 \\
\hline A9 & - & - & $\sqrt{ }$ & - & 30 \\
\hline A10 & - & $\sqrt{ }$ & - & - & 65 \\
\hline A11 & - & $\sqrt{ }$ & - & - & 65 \\
\hline A12 & - & $\sqrt{ }$ & - & - & 65 \\
\hline A13 & - & - & $\sqrt{ }$ & - & 30 \\
\hline
\end{tabular}

Sumber : Hasil analisis, 2019

Pada Tabel 14 dapat diketahui tingkat kerugian hak milik pribadi terjadi pada lokasi A2, A3, A4, A10, A11, A12 sebesar $80 \%$ hal tersebut terjadi karena genangan berada pada daerah padat penduduk dengan tinggi genangan yang relative tinggi menyebabkan genangan dapat masuk kedalam rumahrumah penduduk.

\subsection{Penentuan Skala Prioritas}

Penentuan skala prioritas dapat diketahui dari penambahkan keseluruhan nilai yang didapatkan dari setiap Parameter. Adapun hasil prioritas yang diperoleh pada Tabel 15.

Tabel 15. Hasil perhitungan skala prioritas

\begin{tabular}{|c|c|c|c|c|c|c|c|c|c|}
\hline \multirow{2}{*}{ No } & \multirow{2}{*}{ Lokasi } & \multicolumn{6}{|c|}{ Parameter } & \multirow{2}{*}{$\Sigma$ Nilai } & \multirow{2}{*}{ Priorita } \\
\hline & & 1 & 2 & 3 & 4 & 5 & 6 & & \\
\hline \multirow[t]{2}{*}{1} & $\mathrm{~A} 1$ & 0 & 30 & 65 & 65 & 100 & 30 & 290 & 4 \\
\hline & A2 & 41.25 & 30 & 0 & 100 & 100 & 65 & 336 & 2 \\
\hline \multirow{2}{*}{2} & $\mathrm{~A} 3$ & 41.25 & 30 & 0 & 100 & 100 & 65 & 336 & 2 \\
\hline & A4 & 41.25 & 30 & 0 & 100 & 100 & 65 & 336 & 2 \\
\hline \multirow{2}{*}{3} & A5 & 10 & 30 & 0 & 100 & 30 & 30 & 200 & 7 \\
\hline & A6 & 10 & 30 & 0 & 100 & 30 & 30 & 200 & 7 \\
\hline 4 & A7 & 0 & 30 & 30 & 100 & 65 & 0 & 225 & 6 \\
\hline 5 & A8 & 0 & 30 & 30 & 100 & 65 & 0 & 225 & 6 \\
\hline \multirow[t]{2}{*}{6} & A9 & 8.75 & 30 & 0 & 100 & 100 & 30 & 268 & 5 \\
\hline & A10 & 67.5 & 30 & 65 & 65 & 100 & 65 & 392 & 1 \\
\hline \multirow[t]{2}{*}{7} & A11 & 67.5 & 30 & 65 & 65 & 100 & 65 & 392 & 1 \\
\hline & A12 & 67.5 & 30 & 65 & 65 & 100 & 65 & 392 & 1 \\
\hline 8 & A13 & 45 & 30 & 65 & 65 & 65 & 30 & 300 & 3 \\
\hline
\end{tabular}

Pada Tabel 15 dapat diketahui bahawa urutan skala prioritan genangan/banjir dari yang tertinggi sampai terendah, dengan lokasi prioritas pertama yaitu A10, A11, dan A12 yang terletak pada Kelurahan Tanjungpura. Hal tersebut dikarenakan lokasi A10, A11, dan A12 merupakan daerah dengan kepadatan penduduk cukup padat, tinggi genangan yang cukup tinggi berkisar antara 50-30 cm. Genangan yang 
berlokasi pada daerah pemukiman yang padat menyebabkan banyak kerugian yang dialami warga mulai dari kerugian pada jalur transportasi sampai dengan kerugian terhadap harta benda milik pribadi.

Hasil penilaian skala prioritas untuk Kecamatan Karawang Barat untuk seluruh kelurahan dapat dilihat pada Gambar 3.

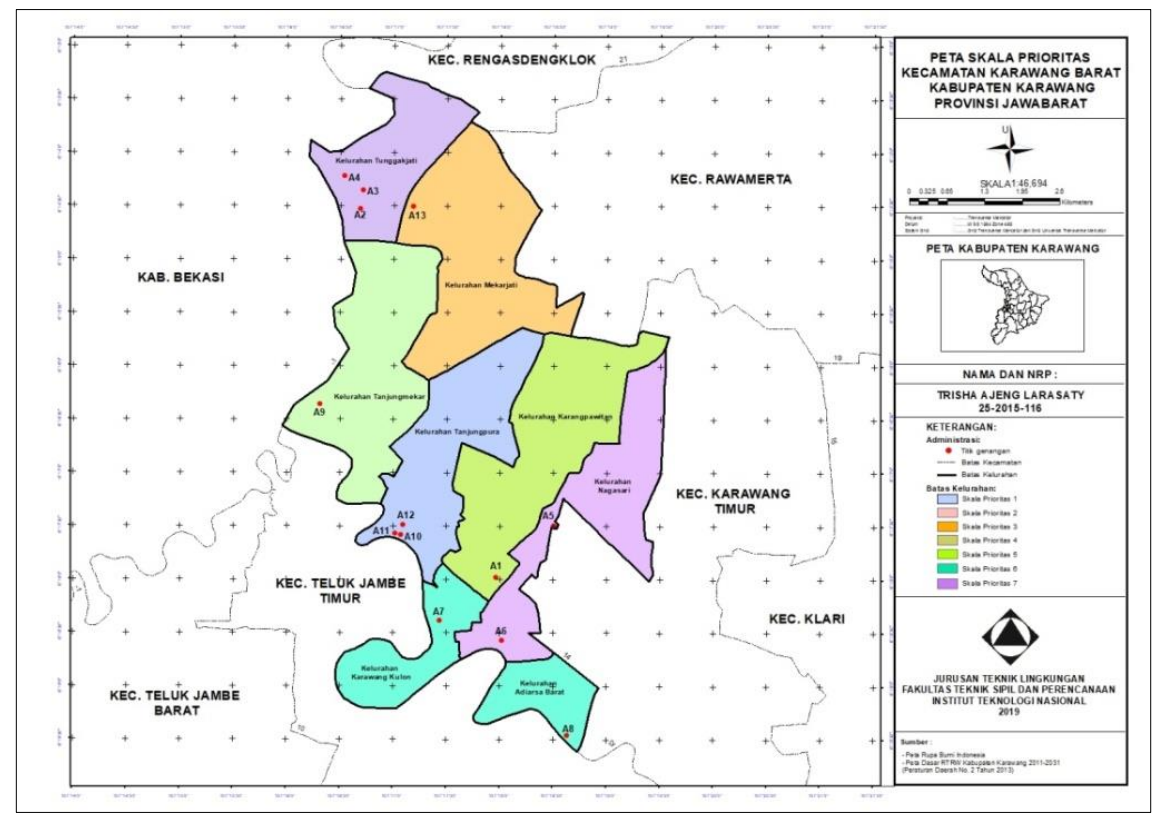

Gambar 3. Skala prioritas genangan/banjir Sumber :Hasil analisis, 2019

\section{Kesimpulan}

Penentuan tingkat prioritas genangan di Kecamatan Karawang Barat ditentukan berdasarkan parameter yang terdapat pada Peraturan Menteri Pekerjaan Umum No. 12 Tahun 2014. Dari hasil tersebut didapatkan kesimpulan yaitu skala prioritas genangan pada Kecamatan Karawang Barat terletak di Kelurahan Tanjungpura terdapat 3 titik genangan dengan tinggi genangan berkisar $50-30 \mathrm{~cm}$, luas genangan $1 \mathrm{Ha}$, dan lamanya genangan berlangsung selama $10 \mathrm{jam}$, Selain itu, genangan berlokasi pada daerah pemukiman padat penduduk yang menyebabkan banyak kerugian yang dialami warga. Hal tersebut yang berpengaruh terhadap penilain skala prioritas dan menjadikan Kelurahan Tanjungura sebagai skala prioritas pertama.

\section{Daftar Pustaka}

[1] Peraturan Daerah Kab. Karawang No 2 Thn 2013 Tentang Rencana Tata Ruang Wilayah Kabupaten Karawang Tahun 2011-2031.

[2] Kecamatan Karawang Barat Dalam Angka. Kecamatan Karawang Barat Dalam Angka, Karawang. 2018

[3] Peraturan Daerah Kab. Karawang No. 2 Tahun 2013 Tentang Rencana Pembangunan Jangka Panjang Daerah Kabupaten Karawang Tahun 2005-2025.

[4] Harminto, Awang Deny. Skripsi Analisis Kebijakan Tentang Penanganan Alih Fuungsi Lahan di Kota Semarang (Daerah Resapan Air Di Kelurahan Sambiroto, Kecamatan Tembalang, Kota Semarang) Universitas Diponegoro Semarang Jurusan Administrasi Publik Fakultas Ilmu Sosial dan Ilmu Politik : Semarang. 2012.

[5] KR Brata, Nelistya. Lubang Resapan dan Biopori. Penebar Swadaya: Depok. 2008

[6] Zahra, V Widia. Penyusunan Skala Prioritas Sistem Drainase di Tiga Kecamatan. Jurnal Online Mahasiswa Fakultas Teknik Universitas Riau Vol 5., No.1. 2018

[7] Suripin. Sistem Drainase Untuk Perkotaan yang Berkelanjutan. Yogyakarta: Andi. 2004

[8] Sujatmoko. Aplikasi Sistem Informasi Geografis Dalam Mengatasi Banjir Pada Sistem Drainase Di Pekanbaru. Universitas Riau. 2016

[9] Tripathi. Flood disaster in India: an analysis of trend and preparedness. Interdiscip J Contemp Res, 2(4), 91-98. 2015 
[10] Miardini, Arina. Penentuan Prioritas Penanganan Banjir Berdasarkan Tingkat Kerawanan Menggunakan Topographic Wetness Index: Studi Kasus di DAS Solo Vol 17., No. 1, 113-119. 2019

[11] Peraturan Menteri Pekerjaan Umum dan Perumahan Rakyat No.12 Tahun 2014 tentang Penyelenggaraan Sistem Drainase Perkotaan. 2014

[12] Prasetyo, E. Studi Evaluasi Normalisasi Sistem Drainase Tanjung Sadari Krembangan Surabaya. 2013

[13] W, Haneda. Analisis Penentuan Lokasi Prioritas Penanganan Genangan Banjir pada Kecamatan Cimahi Tengah Seminar Nasional Cendekiawan ke 5 Tahun 2019. 2019

[14] Rencana Strategis Dinas Perumahan Rakyat dan Kawasan Pemukiman Kabupaten Karawang 20162021.

[15] BAPPEDA. Peta Penggunaan Lahan Kecamatan Karawang Barat. 2012 